\title{
Mulheres de Galícia
}

\author{
Muller e emigración.
}

VILA, Pilar Cagiao.

Santiago de Compostela: Xunta de Galicia, s/d. 202 p.

\section{Nais, xornaleiras e emigrantes. Unha perspectiva comparativa da muller na emigración americana e europea.}

\author{
PARENTE, Mariluz González; PAZOS, \\ Marta Lombán.
}

Galícia: Concello de Santiago/ Consorcio de Santiago/Universidade de Santiago de Compostela, 2000. 82 p.

Para Zahidé Machado Neto e Maria del Rosário Alban

Há poucas décadas, com o desenvolvimento dos estudos feministas, posteriormente denominados de gênero, denotando o caráter de construção social das sexualidades, a mulher foi alçada à condição de Sujeito da história, dotada de voz e participação nas tramas e configurações das sociedades e culturas. Entretanto, se de um ponto de vista geral a Academia reconhecia sua importância, em áreas específicas, como nos trabalhos sobre os imigrantes, a mulher ainda permanecia como coadjuvante, um acessório para referendar o primado masculino, quando não simples componente de estatísticas.

Em pequeno livro sobre o Romanceiro da imigração japonesa (São Paulo: Editora Sumaré, 1993), Célia Sakurai, com pertinência, constata que a mesma experiência da imigração é vivenciada de forma diferenciada sob a ótica masculina e a feminina. O significado de 'vencer na vida' é concretizado para os homens na trajetória no mundo do trabalho, através de uma vida fora de casa. Já para as mulheres o ponto de partida é sempre o universo doméstico, com a presença da mãe como o arcabouço essencial para a vitória do grupo familiar. Considerando 0 caráter patriarcal da família japonesa, ao homem cabe a responsabilidade por si e pelo grupo, sendo a mulher interpretada como colaboradora do marido. Porém, os romances desvendam as atividades fundamentais desempenhadas pelas mulheres: a socialização e o cuidado dos filhos, a preservação da língua e dos valores do grupo, a responsabilidade e as adaptações da alimentação e do vestuário, a comunicação através das cartas - com a sociedade de origem.

No meu livro sobre os imigrantes galegos, Galegos no paraíso racial (Salvador: lanamá/ Ceao/CED, 1994), observara em relação à primeira fase (1880-1930) da emigração galega para a Bahia as suas conseqüências nas 
províncias de origem e na sociedade de destino: uma sociedade de mulheres na Galícia e uma sociedade de homens em Salvador. Na época da sua elaboração, pensava na necessidade, em especial considerando a situação galega, de estudos sobre a imigração estrangeira que contemplassem de forma primacial a participação da mulher. Portanto, foi com entusiasmo que recebi das mãos de Pilar Cagiao Vila, em 2000, o seu livro denominado Muller e emigración (Santiago de Compostela: Xunta de Galicia, s/d). Nele, a autora, pesquisadora renomada em estudos sobre a emigração galega, utilizando ampla bibliografia, pesquisa documental e testemunhos orais, demonstra o real significado da participação da mulher na emigração galega. Primeiro, mostra de forma detalhada a presença da mulher galega, embora menor e mais tardiamente, nas diversas fases históricas do longo processo emigratório galego. A partir de alguns exemplos, enfatiza a necessidade de estudos sobre as exiladas, absolutamente esquecidas nos estudos sobre a imigração galega. Em seguida, oferece um aporte sobre a mulher nos principais destinos americanos.

Inicialmente, atenta para a emigração em massa dos homens, com a mulher permanecendo na Galícia e sendo obrigada a desempenhar múltiplos papéis em relação à casa e à família. As mulheres tiveram que assumir trabalhos duros, tradicionalmente reservados aos homens, como trabalhar a terra, cuidar do gado, transportar, comprar e vender peixe, além das costumeiras atividades domésticas. As conseqüências de tal composição demográfica tiveram efeitos em vários planos: a presença marcante de velhos $e$ crianças, alto celibato feminino, generalização de mães solteiras, além das célebres 'viúvas de vivos', com maridos emigrantes que jamais retornaram. Já como protagonistas diretas do fenômeno emigratório, além de enfrentar as mesmas situações dos homens, tiveram acrescidas aquelas relacionadas à sua condição de gênero. Porém, Pilar Cagiao Vila ressalta a inexistência de um modelo único, pois, apesar do objetivo comum de melhorar de vida, as diferentes situações da migração e a vivência diferenciada de cada mulher deram lugar a formas distintas de imigradas, cumprindo-se ou não os seus projetos de partida.

Nos países americanos, além das tradicionais responsabilidades no âmbito familiar, as mulheres tiveram um complexo papel de adaptação e integração, sendo dependentes de sua situação pessoal e das condições apresentadas pelas sociedades receptoras, problemas, de resto, enfrentados também pelos homens. Porém, no caso das mulheres o esforço foi muito maior, devido à organização patriarcal da família, baseada em tradicionais padrões culturais. A autora salienta que a mulher que não trabalhou fora de casa permaneceu vinculada aos seus papéis tradicionais, tendo, por seu menor contato com o 'mundo da rua', o entorpecimento do seu processo de integração. Já a mulher que participou diretamente do mercado de trabalho, de forma geral, integrou-se em formas irregulares de emprego e no setor de serviços, com trabalhos domésticos, de limpeza, costura e outras atividades correlatas, nos níveis mais baixos da estrutura ocupacional. E tinham como adicional a sua condição de gênero, o que as igualava às nacionais pobres das sociedades receptoras - a situação étnica como componente dos fatores de discriminação que as afetavam diretamente.

À proporção que foram consolidando a sua condição de imigrante, as mulheres galegas iam aceitando os novos símbolos e valores das sociedades receptoras, mas ao mesmo tempo mantinham as suas próprias características culturais, possibilitando em muitos planos - língua, contatos, através das cartas, socialização dos filhos, alimentação - a presença da Galícia na sociedade de adoção.

Pequeno livro, tratando sobre tema conexo, recebi das jovens pesquisadoras Mariluz González Parente e Marta Lombán Pazos, vencedor na Galícia do Prêmio Xohana Torres de Investigación 1999, denominado Nais, xornaleiras e emigrantes. Unha perspectiva comparativa da muller na emigración americana e europea (Galícia: Concello de Santiago/ Consorcio de Santiago/Universidade de Santiago de Compostela, 2000). Nele, a emigração é estudada sob a perspectiva de gênero, através da utilização de documentação secundária sobre a história da emigração e tendo como suporte metodológico da investigação as fontes orais, ou seja, entrevistas extensas com mulheres emigrantes.

Embora com uma amostra de pequena abrangência, além da carência de fontes demográficas, o que limita o seu escopo, de certa forma, reitera e complementa o livro de Pilar Cagiao Vila. Inicialmente, questiona: por que são tão poucas as mulheres que emigram? Para as autoras, houve sempre opiniões contrárias à emigração feminina, seja pela legitimação do modelo familiar estabelecido e pela relação comunitária familiar, seja pela imagem negativa de vários países, como Cuba e Brasil. As notícias 
revelavam as impressões sobre o forte calor no Brasil, o que provocava muitas doenças, e, como adicional componente, a presença de uma grande população negra, o que muito assustava galegos e galegas. Para completar o quadro, eram vários os relatos da existência de 'máfias' espanholas que buscavam arregimentar as patrícias para o exercício da prostituição. Isso determinou o estabelecimento de uma legislação paternalista e restritiva à emigração feminina que se manteve até a década de 50 do século XX: as mulheres casadas precisavam obter permissão dos maridos para emigrar e as mulheres solteiras e menores necessitavam da autorização dos pais.

A primeira parte do livro - reiterando, embora de forma limitada, a perspectiva de Vila - concentra-se na vivência das mulheres na Galícia. A partir de então, as autoras abordam o período que vai dos finais da Segunda Guerra Mundial até os anos 60, momento em que países como Brasil e Argentina importavam mão-de-obra para suprir as necessidades dos seus parques industriais e o destino europeu ganhava força e representatividade, momento em que já não se permitia a entrada indiscriminada, mas sim segundo os critérios de seleção de emigrantes de cada país. Uma emigração que, em muitos aspectos, seja pela mudanças operadas na Espanha, seja pelas transformações que se processavam nos países receptores, era muito diferenciada da fase pioneira.

A emigração, masculina ou feminina, ainda provém do mundo rural. As informantes que emigraram, de forma geral, tiveram apenas 0 aprendizado básico na escola - ler, escrever e contar. Mas recordavam que, antes de iniciar a experiência emigratória, as suas vivências foram marcadas pela rotina da vida no campo e pela liturgia da religião católica - um dos pilares do franquismo. Já na condição de imigrantes, as autoras analisaram as diferenças entre as suas condições na América e na Europa, centrandose no caso brasileiro e francês, para evidenciar, a partir de informantes específicas, a sua forma de inserção e respectiva vivência nas sociedades receptoras.

Com as suas devidas características, ambos são excelentes trabalhos para demonstrar a importância da mulher no processo emigratório galego e para referendar o seu significado na constituição do grupo étnico nas sociedades receptoras. Uma Galícia que permaneceu viva na América e na Europa devido aos sonhos, à vontade, à dedicação, à luta das mulheres da Galícia. 